\title{
GOING GENTLY INTO THAT GOOD NIGHT: THE CONSTITUTIONALITY OF CONSENT IN CASES OF EUTHANASIA
}

\author{
Samantha Krause \\ LLB LLM PhD \\ Post-doctoral Research Fellow \\ University of KwaZulu-Natal
}

\begin{abstract}
SUMMARY
Although consent is a justification ground in South African law, its applicability to cases of euthanasia has been the subject of controversy. It is submitted that relying on the distinction between omission and commission, or causation or intent will not prove useful in justifying mercy killing. In terms of the South African Constitution (and various human rights guaranteed therein), there may be compelling arguments for legalizing euthanasia. For instance, section 10 of the Constitution guarantees the right to dignity. A lack of control over your destiny essentially involves a loss of dignity. Further, the right to dignity and the qualified right to personal autonomy inform section 14: the right to privacy. This right holds that an individual can make certain fundamental private choices without state interference. Surely this would extend to how to end one's life? This article advocates that a rights-based approach be used to inform the doctrine of consent. This would entail taking the victim's shared responsibility into account thereby reducing the perpetrator's fault.
\end{abstract}

\section{INTRODUCTION}

In 2002 the European Court of Human Rights weighed in on the subject of assisted suicide in the case of Pretty $v$ United Kingdom. ${ }^{1}$ The international tribunal stated its position regarding an individual's right to self-determination However, the Strasbourg court relied heavily on the common law positions for guidance in Pretty. Common law courts including the United States Supreme Court depend on linguistic distinctions in regard to an individual court's right to self-determination. ${ }^{2}$ In analyzing the Strasbourg court's application of article 8 to assisted suicide, this article explores both the decision in Pretty $v$ United Kingdom and jurisprudential decisions in the United States regarding the right to assisted suicide. Before South African courts can recognize a universal right to die, it will be necessary to first

[2002] 35 EHRR 1.

Nugent ' WWalking into the Sea' of Legal Fiction: An Examination of the European Court of Human Rights, Pretty v United Kingdom and the Universal Right to Die" 2003 Journal of Transnational Law and Public Policy 183185. 
determine whether the distinctions between acts and omissions, or causation or intention provide any useful basis on which the courts can distinguish between active and passive euthanasia. ${ }^{3}$ It will be demonstrated that these distinctions are not sufficient to justify assisted suicide. For this reason, it is submitted that the courts should look at a constitutional basis to inform the defence of consent regarding euthanasia.

\section{SOUTH AFRICAN LAW}

Consent is recognized in our law as a ground of justification, providing the following criteria are met:

- Consent in the circumstances must be recognized by the law as a possible defence.

- It must be real consent.

- It must be given by a person capable of consenting. ${ }^{4}$

Therefore, for consent to operate as a defence, it must be part of the definitional elements of the crime, and in "such circumstances will cleanse the act of its criminal nature as a result of the application of the principle volenti non fit injuria." ${ }^{5}$ The rule extends to cases where a person is able to consent to the risk of serious bodily injury or death during the course of normal medical treatment. ${ }^{6}$ Although suicide is considered legal, ${ }^{7}$ the common law does not permit the consent of the victim to act as a defence where the victim consents to being killed. This is traditionally regarded as being against the legal convictions of society and is therefore unlawful. ${ }^{8}$ However, not all case law demonstrates that the courts have strictly followed this rule. ${ }^{9}$ It would appear as if one of the central questions surrounding the continued criminalization of such acts is the question of causation, more particularly whether there is a "novus actus interveniens" 10 breaking the causal link between the perpetrator's conduct and the death. In other words, was there a direct act on the part of the perpetrator (which would have a contributory effect to the death) and if there was, was it interrupted by a break in the causal chain of events following that act that would prevent liability from ensuing.

This question has been dealt with on a number of occasions by our courts. In $R v$ Nbakwa ${ }^{11}$ the accused, who lived according to cultural beliefs, accused the deceased (his mother) of witchcraft in the sense of causing his

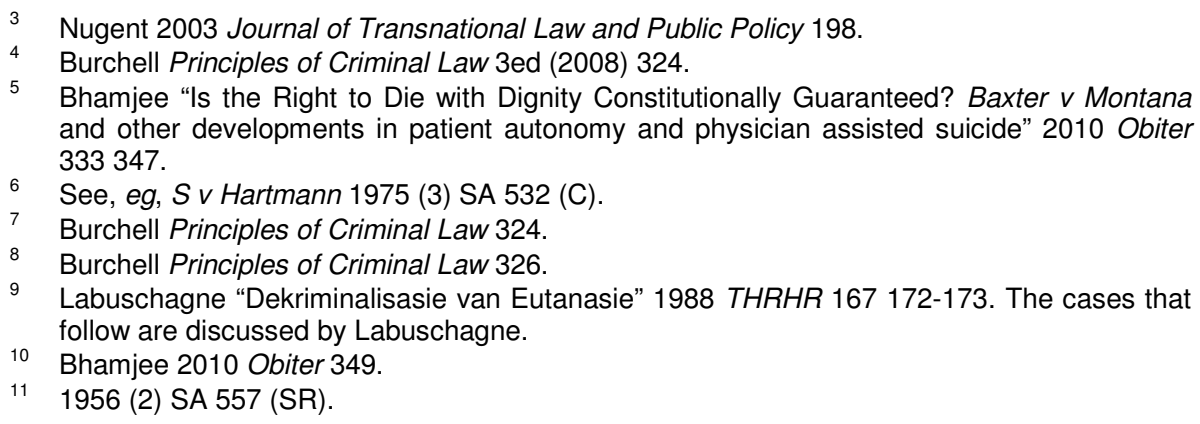


child to die, and incited her to kill herself. The question was whether the accused's "acts" could be construed as an attempt to kill the deceased (or possibly lead to attempt liability). Beadle JA found that the acts went no further than "what is commonly called acts of preparation". What the judge found pertinent was that, although the accused provided the means to cause death and persuaded the victim to kill herself, the actual act which caused the death of the woman was the act of the woman herself. ${ }^{12}$ The judge noted that there was "a novus actus interveniens between the actions of the accused and death of the deceased which broke the chain of causation." ${ }^{13}$

In $S v$ Gordon $^{14}$ the accused provided the deceased with tablets, knowing that he would take them and probably die. Henning $J$ noted that "the cause of her death was her own voluntary and independent act in swallowing the tablets" and although he "undoubtedly aided and abetted her to commit suicide ... that is not an offence". Although "he intended her to die is undisputable ... his own acts calculated to bring about that result fall short of a killing or an attempted killing". ${ }^{15}$

In $S v$ Hibbert ${ }^{16}$ the accused's wife wanted to commit suicide. He assisted her in that purpose by providing her with a loaded gun. The judge noted that the accused had set in motion a chain of events which ended in his wife pulling the trigger. The successive words and actions of the accused were designed to place her in possession of the fire-arm and were accompanied by the hazard that she might be persuaded to carry out the act which killed her. What is clear is that the accused's conduct only fell short of the final act of pulling the trigger. In this case the court focused purely on the issue of causation, holding that the accused was both the legal and factual cause of his wife's death. ${ }^{17}$ What was interesting to note was that the court avoided answering an important point of approving a general doctrine that the last voluntary and independent act of the person committing suicide must always bring about the acquittal of the accused (without some reservation in regard to the independence of the act). It is undoubtedly so that the totally unconnected act of another who is the immediate cause of a result necessarily interrupts or excludes the causality of the perpetrator's act. This would not be the case where the act or behaviour of the perpetrator is indeed the primary cause of the act, although the act itself is innocent. ${ }^{18}$

What the discussion of these cases demonstrates is that the person who performs the final act (whether it is swallowing the tablets, stabbing themselves with a knife etcetera) is the legal cause of the death. What about cases of passive euthanasia? As a general rule, courts are less willing to prosecute cases of passive euthanasia (that is, withholding of life-support). It

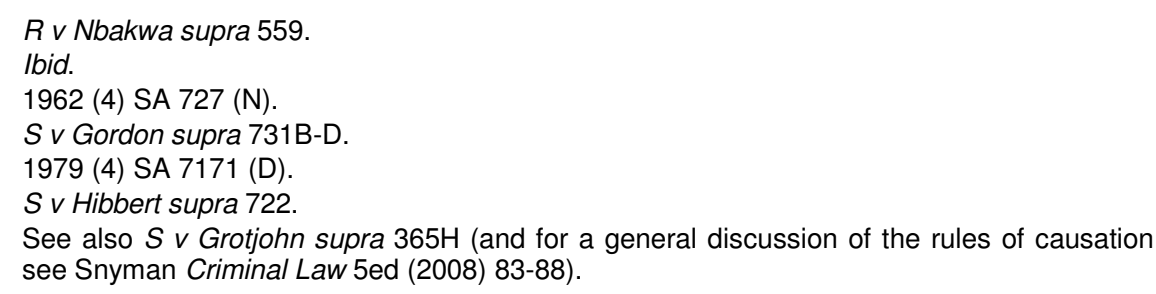

See also $S v$ Grotjohn supra $365 \mathrm{H}$ (and for a general discussion of the rules of causation see Snyman Criminal Law 5ed (2008) 83-88). 
is submitted, however, that the distinction between these two forms of euthanasia and subsequent culpability or lack thereof cannot be maintained.

\section{CAUSATION}

It is submitted that from a legal point of view, the distinction between active and passive euthanasia is not at all clear and is based on semantics. ${ }^{19}$ This contention is based on the court's comments that "a patient [who] refuses life-sustaining medical treatment, dies from an underlying fatal disease or pathology; but if [he] ingests legal medication prescribed by a physician, he is killed by the medication" ${ }^{20}$ In other words, the former is caused by natural causes, the latter is not. ${ }^{21}$ Consider the case of In re Quinlan, ${ }^{22}$ where a young woman, who for unexplained reasons lapsed into a "chronic and persistent vegetative state". ${ }^{23}$ Although she required a ventilator and artificial means of sustenance in terms of the legal standard recognized by the State of New Jersey, and in terms of medical practice, she was considered alive. ${ }^{24}$ Given that Ms Quinlan did not have advance medical directives, her father sought guardianship over her and petitioned the court to terminate her treatment. ${ }^{25}$ Although evidence presented by the father lacked probative weight, the New Jersey Supreme Court based its withdrawal of life support on the state's medical standards and ethics. In defining what constituted passive euthanasia, the court likened the withdrawal of life support to the hospital's treatment of terminally ill patients who die naturally. Doctors testified to an "unwritten and unspoken standard of medical practice: DNR". This means that health-care workers are prevented from taking extraordinary measures to resuscitate terminally-ill patients. ${ }^{26}$ Along similar lines, the court in Pretty $v$ United Kingdom ${ }^{27}$ noted that "the refusal to accept particular treatment might, inevitably, lead to a fatal outcome, yet the imposition of medical treatment without the consent of a mentally competent adult patient, would interfere with a person's physical integrity in a manner capable of engaging the rights protected under Article 8(1) of the Convention." ${ }^{28}$ The causation argument could follow that, unlike active euthanasia, with passive euthanasia, the disease or nature is responsible for the patient's death when life-sustaining treatment is discontinued. ${ }^{29}$ This is not correct since if the physician's actions are not the cause of the patient's death, then the

\footnotetext{
Nugent 2003 Journal of Transnational Law and Public Policy 204.

Quill v Vacco 521 US 793 (1997) 801.

Nugent 2003 Journal of Transnational Law and Public Policy 204.

355 A.2d 647 (N.J), (1976).

In re Quinlan supra 655.

24 In re Quinlan supra 652, discussed in Nugent 2003 Journal of Transnational Law and Public Policy 204.

25 In re Quinlan supra 653, discussed in Nugent 2003 Journal of Transnational Law and Public Policy 204-205.

26 In re Quinlan supra 657, discussed Nugent 2003 Journal of Transnational Law and Public Policy 205.

2735 European Human rights Report 1 36-37 (2002).

28 Convention for the Protection of Human Rights and Fundamental Freedoms 1950 U.N.T.S. 222 36, discussed in Nugent 2003 Journal of Transnational Law and Public Policy 207.

29 Ibid.
} 
causation argument will prevent the state from prosecuting anyone who decides to terminate life support or refuse life-sustaining treatment against the patient's wishes. ${ }^{30}$ Further, passive euthanasia requires actions such as turning off a ventilator which causes suffocation, terminating dialysis, produces symptoms of uraemia, and refusing feedings produces symptoms of dehydration or starvation. ${ }^{31}$ Further it could be said that passive euthanasia goes against notions of a physician's duty to his patient where the physician's omission of readily available treatment is the textbook definition of professional malpractice. ${ }^{32}$

Furthermore, in cases where "patients decide to forgo or withdraw basic care such as food and water, the claim that death is 'caused' as much by human choice as any death by lethal injection has some undeniable appeal". ${ }^{33}$ For example, a driver who operates his vehicle at an excessive speed arrives at the street corner just before a child runs across the road. The question then is whether the driver's excessive speed "caused" the death. What if the situation was different and the driver knew that the child would run across the road and the driver calculated his speed in order to arrive at the precise moment the child enters the road? Does this fact change or strengthen our view about the cause of the death? Therefore, what we perceive as a "causal force may be determined less by a mechanical review of the physical evidence than by an assessment of someone's mental state, our sense of justice, or common sense". ${ }^{34}$ To say that nature is responsible for the deaths in right-to-refuse cases is like saying that speed is responsible for the death of a child crossing the street when a driver set off knowing the child would run in front of his car and die. Although it is a causal factor, it is not the only one. ${ }^{35}$ What becomes apparent is that a factual causal connection is not enough to entail legal liability. ${ }^{36}$ Does this mean that there has to be an additional factor? Theorists such as Williams have suggested that the further test to be applied to the "but-for" cause (conditio sine qua non) in order to qualify as legal causation is not a test for causation but a moral reaction. ${ }^{37}$ The question is whether the result can fairly be said to be imputable to the accused. In other words, it involves a value judgment. ${ }^{38}$ Other theorists have favoured an "adekwate veroorsakingstoets". ${ }^{39}$ To establish legal causation, the adequate-cause test asks whether in the normal course of events, according to human experience, the act has a tendency to bring about that situation. Therefore, where a doctor assists a

30 Nugent 2003 Journal of Transnational Law and Public Policy 207.

Nugent 2003 Journal of Transnational Law and Public Policy 205.

Nugent 2003 Journal of Transnational Law and Public Policy 207.

33 Gorsuch "The Right to Assisted Suicide and Euthanasia" 2000 Harvard Journal of Law and Public Policy 600645.

34 Gorsuch 2000 Harvard Journal of Law and Public Policy 643.

35 Gorsuch 2000 Harvard Journal of Law and Public Policy 645.

36 Clarke v Hurst NO [1992] 4 All SA 763 (D) 789, discussing S v Mokgethi 1990 (1) SA 32 (A) 40

37 Williams Textbook of Criminal Law 2ed (1983) 381, discussed in Clarke v Hurst NO supra 700 .

38 Clarke $v$ Hurst NO supra 763.

39 For instance Snyman Criminal Law 85. 
patient's suicide by prescribing an excessive dose of drugs, he will be the legal cause of that patient's death. ${ }^{40}$ The fact that the patient is terminally ill will be no defence. ${ }^{41}$ This is so because the doctor not only changes the course but also the cause of the patient's death. ${ }^{42}$

The question which needs to be considered is what happens in cases where doctors have withdrawn life-support from terminally-ill patients. Could such an act be regarded as a "new intervening act" (novus actus)? This issue was raised in the case of $S v$ Williams, ${ }^{43}$ where along similar lines, the court held that such an act by a doctor does not break the causal sequence set in motion by the accused who had inflicted the initial wounds on the deceased which necessitated her being placed on a respirator. ${ }^{44}$ Surely the same reasoning could be applied in cases where doctors withdraw lifesupport from terminally-ill patients who are already in the process of dying. In other words, nothing can be done to reverse the process of death. What becomes apparent is that many factors will have to be considered by the courts and that matters of policy are relevant to the enquiry and that the court will have to guard against allowing liability to exceed the bounds of reasonableness, fairness and justice. ${ }^{45}$

\section{ACT-OMISSION}

In Quill $v$ Vacco ${ }^{46}$ the court offered another distinction between assisted suicide and refusal of medical treatment, arguing that the former involves an affirmative act while the latter amounts to an omission. As a result of this, culpability will differ. ${ }^{47}$ The Second Circuit Federal Appeal Court rejected this act-omission distinction stating that "[t]he writing of a prescription to hasten death ... involves a far less active role for the physician than is required to bring about death through asphyxiation, starvation, or dehydration". ${ }^{48}$ The problem is that although the act-omission distinction is entrenched in South African doctrinal law, it can be easily subject to manipulation. ${ }^{49}$ In Airedale N.H.S. Trust $v$ Bland $^{50}$ a British teenager was crushed while standing in a spectators' pen at an English soccer match. These injuries left him in a

40 Burchell Principles of Criminal Law 213.

41 Snyman Criminal Law 80.

42 Clarke $v$ Hurst NO supra 701.

$43 \quad 1986$ (4) SA 1188.

$44 \quad S \vee$ Williams supra 606FF.

45 Clarke v Hurst NO supra 789, discussing S v Mokgethi supra 40.

46 Quill v Vacco supra 801.

47 Cormack "Euthanasia and Assisted Suicide in the Post-Rodriquez Era: Lessons from Foreign Jurisdictions" 2000 Osgoode Hall LJ 591611.

48 Quill v Vacco supra 729.

49 See further Soobramoney $v$ Minister of Health (KwaZulu-Natal) 1998 (1) SA 765 (CC) par [326]-[327], where the Constitutional Court held that the state can legitimately withhold medical treatment necessary for the preservation of life if the state's resources to provide such treatment are limited. As Jordaan "The Right to Die with Dignity: A Consideration of the Constitutional Arguments (1)" 2009 THRHR 192 211-212 has noted, this amounts to an inconsistency on the state's part if it can withhold treatment on the one hand but refuse to recognize voluntary euthanasia on the other.

502 W.L.R. 316 (1993). 
vegetative state. Although he was not dying, he required food and water tubes so that he could live in a comatose state. The House of Lords agreed to the removal of Bland's tubes. Withholding such treatment would constitute an omission and Lord Browne-Wilkinson went on to articulate why it could be classified as such:

"The positive act of removing the nasogastric tube presents more difficulty. It is undoubtedly a positive act, similar to switching off a ventilator in the case of a patient whose life is being sustained by artificial ventilation. But in my judgment in neither case should the act be classified as positive, since to do so would be to introduce intolerably fine distinctions. If, instead of removing the nasogastric tube, it was left in place but no further nutrients were provided for the tube to convey to the patient's stomach that would not be an act of commission. Again, as has been pointed out ... if the switching off of a ventilator were to be classified as a positive act, exactly the same result can be achieved by installing a time-clock which requires to be reset every 12 hours: the failure to reset the machine could not be classified as a positive act."

It is clear that this line of reasoning reflects the difficulties in reconciling the act-omission doctrine with acceptable medical practice. ${ }^{52}$ The problem with this is that nowhere did the court explain why they viewed the removal of his tubes as an "omission" rather than an "active" step. ${ }^{53}$ This point was also demonstrated in Clarke $v$ Hurst $N O,^{54}$ where Thirion $\mathrm{J}$ held that in determining legal liability "there is [no] justification for drawing a distinction between an omission to institute artificial life-sustaining procedures and the discontinuance of such procedures once they have been instituted". The judge went on to hold that "there is [no] virtue in classifying the discountenance of such procedures as an omission" ${ }^{55}$ In both these cases, even if the court(s) had offered a convincing reason for the classification, they failed to offer any reason why it would make a moral or legal difference. ${ }^{56}$ Even Dutch law acknowledges that euthanasia embraces "all activities or non-activities with the purpose to terminate a patient's life". ${ }^{57}$

\section{$5 \quad$ INTENTION}

Utilizing intention as a cogent means to distinguish between active and passive cases of euthanasia would prove fruitless in South African law. Consider the way the United States case law has developed in this regard. In that jurisdiction, the distinction between killing and letting die, does in fact have profound intent-based moral and legal significance. ${ }^{58}$ An intentional action differs not only morally but also legally from an unintended consequence. Unlike unintended consequences, it could be said that

\footnotetext{
Airedale N.H.S. Trust $v$ Bland supra 881-882.

Cormack 2000 Osgoode Hall LJ 612.

Gorsuch 2000 Harvard Journal of Law and Public Policy 646.

Clarke v Hurst NO supra 763.

Clarke $v$ Hurst NO supra 789.

Ibid.

Ibid.

Gorsuch 2000 Harvard Journal of Law and Public Policy 647.
} 
intentional conduct is always within our control. ${ }^{59}$ In such a case we are specifically referring to direct intention. That is, a person directing his/her will towards a prohibited act. ${ }^{60}$ It follows that the most stringent moral judgments should relate to intentional acts. The primacy of intention explains "why in law and morals a sharp line is drawn between the result, which is intended ... and the certain concomitant, which [is not] intended ... To see a paradox in this distinction assumes that because the result in the world is the same in the two cases the judgment in them must be too ... It ignores the element of purpose." ${ }^{61}$ The problem is that when talking about direct intention, it does not necessarily follow that actions are always within our control. ${ }^{62}$

When considering the issue of intention, the Supreme Court in Quill $v$ $V_{a c c}{ }^{63}$ concluded that refusing care and assisted suicide differ not only in their causes, but subsequently in the intentions behind them. A physician who "withdraws, or honours a patient's refusal to begin, life-sustaining medical treatment purposefully intends, or may so intend, only to respect his patient's wishes" and "to cease doing useless and futile or degrading things to the patient when [the patient] no longer stands to benefit from them". ${ }^{64}$ The same is true when a doctor provides aggressive palliative care, in some cases, pain-killing drugs may hasten patient's death, but the physician's purpose and intent is, or may be, only to ease his patient's pain. ${ }^{65}$ Such reasoning is flawed since in South African law, although such a doctor may not have direct intention (death is not the main aim and object) ${ }^{66}$ he may have indirect intention in the sense that he knows he can only carry out his patient's wishes by killing the patient ${ }^{67}$ or dolus eventualis, where the doctor foresees the possibility that the death might occur in the same manner that it does and he reconciles himself to this possibility ${ }^{68}$ Clearly such a doctor would still have intent to kill for legal purposes, even if it is not his desire or main aim.

\section{INTENTION AND THE RIGHT TO REFUSE MEDICAL TREATMENT}

In the American case of Washington v Glucksberg $^{69}$ Justice Stevens held that any distinction between suicide and refusing life-saving treatment based on intent is illusory. To support this finding he suggested that a physician discontinuing care could do so with an intent to kill that patient and a doctor

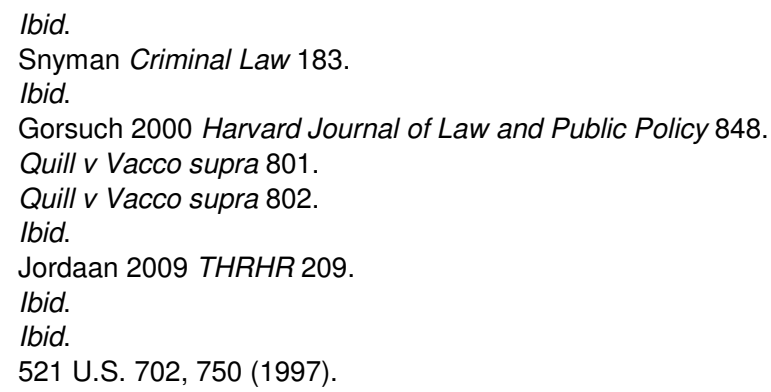


who prescribes lethal medication "may seek simply to ease the patient's suffering and to comply with her wishes". ${ }^{70}$ What this suggests is that the judge views the right to refuse as a species of suicide and assisted suicide (intentional killing) that the state has already sanctioned. ${ }^{71}$ The problem with this contention is that, while intention to kill either as an end or as a means, is an element of assisted suicide and euthanasia; it is not part of the practice of refusing medical care either as a matter of logical necessity or historical development. ${ }^{72}$ Patients may decline further medical care for many reasons which do not imply an intention to die. These include avoiding further pain associated with the invasive treatments. They may wish to avoid the indignity that dependence on medical equipment provides or may wish to be with their loved ones and restore a sense of "privacy". ${ }^{73}$ Further, in terms of South African law, while the doctor may not have direct intent to kill (that is the death is not his main object or goal), he may still have dolus eventualis, if death is not certain as a result of ceasing treatment. ${ }^{74}$ Such a doctor would still have intent for legal purposes, even if it is not his desire or aim. Second, it confuses the issue of the doctor's motive with intent. Where doctors acted with intention, causing the death of the patient, they cannot escape liability by showing that they acted with a good motive (ending the patient's suffering). ${ }^{75}$ Motive is therefore irrelevant in assessing criminal liability. However, it is important to the question of sentencing. ${ }^{76}$

The Washington federal district court in Compassion in Dying $v$ Washington State ${ }^{77}$ suggested that in recognizing the right to refuse the state had carved out a form of permissible suicide. Ironically, the court went on to hold that the state's interest in "the prevention of suicide was not implicated by the new right because a death which occurs after the removal of life-sustaining systems is ... not intended by the patient." ${ }^{78}$ Thus numerous states in the United States have implicitly recognized this intentbased distinction by continuing to hold assisted suicide and euthanasia unlawful even after recognizing a new right to refuse care.$^{79}$ What is clear is that intent provides a rational basis for distinguishing between the right to refuse medical intervention and assisting suicide. ${ }^{80}$

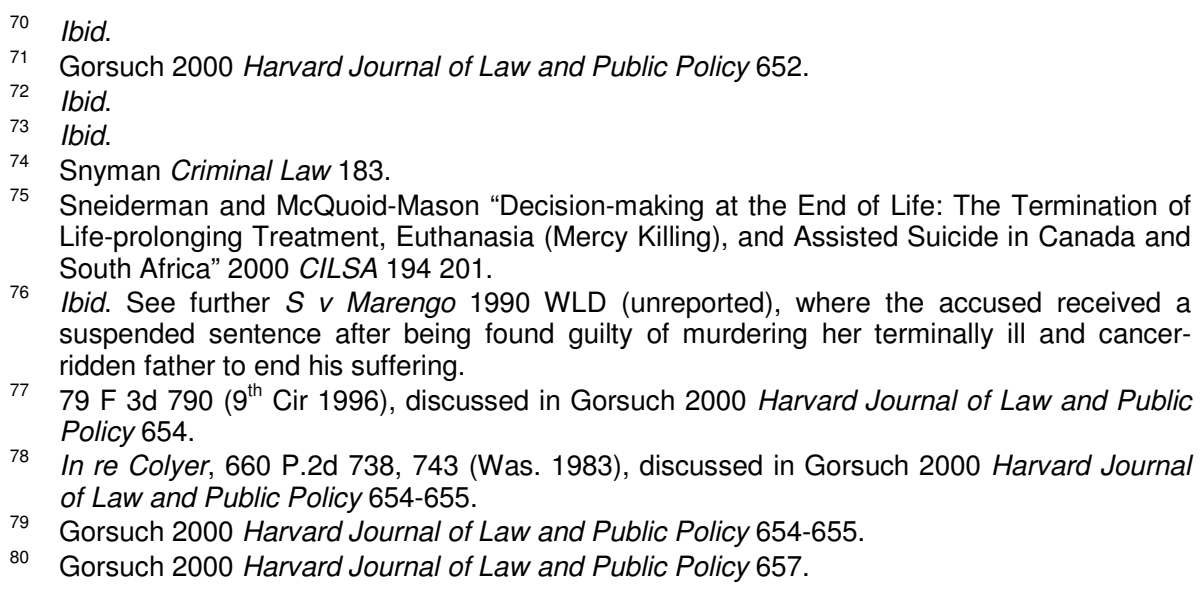

$7779 \mathrm{~F} 3 d 790$ ( $9^{\text {th }}$ Cir 1996), discussed in Gorsuch 2000 Harvard Journal of Law and Public Policy 654.

78 In re Colyer, 660 P.2d 738, 743 (Was. 1983), discussed in Gorsuch 2000 Harvard Journal of Law and Public Policy 654-655.

79 Gorsuch 2000 Harvard Journal of Law and Public Policy 654-655.

80 Gorsuch 2000 Harvard Journal of Law and Public Policy 657. 
Such a distinction would not prove useful in South African law due to the existence of intention in the form of dolus eventualis: where the accused foresees the possibility that the prohibited consequence might occur in the same manner that it does and he reconciles himself to this possibility. ${ }^{81}$ Hastening an individual's death is ordinarily not justifiable and therefore wrongful, even where the person is terminally ill. ${ }^{82}$ But it is submitted that this is not an absolute rule since a doctor may give a terminally-ill patient drugs with the object of relieving his pain even if he is aware of the knowledge that such drugs will shorten the patient's life. ${ }^{83}$ Furthermore, it is submitted that the distinction between holding assisted suicide unlawful while recognizing the right to refuse care is based on an important consideration - society's sense of propriety, most notably its belief that things should happen according to their natural disposition or order. Therefore, a person who preempts the function of the executioner and kills the "condemned man" while he is still taking his last few steps to the gallows, acts wrongfully irrespective of the motive for killing him. ${ }^{84}$ The killer acts wrongfully because he has no right to interfere with the affairs of another. ${ }^{85}$ Consider the distinction between the act of a doctor who follows the ethics of his profession and prescribes a drug in the quantity necessary to relieve pain and the doctor who prescribes an overdose with the object of killing the patient. While the former acts within the legitimate context of his profession, the latter does not. ${ }^{86}$ In such a case society would necessarily judge the conduct in the former as justified in terms of the criterion of reasonableness. The latter would be regarded as wrongful since it would lead to "unauthorized and autocratic decision-making".

\section{BILL OF RIGHTS AND EUTHANASIA}

Since the decision of Clarke $v$ Hurst $N O^{88}$ the Constitution of the Republic of South Africa, ${ }^{89}$ has come into effect. Various fundamental human-rights and democratic values are guaranteed therein. ${ }^{90}$ The legal convictions of society are now also informed by reference to such constitutional values. ${ }^{91}$ Several of these values have formed the basis of the recommendations of the Law Commission's Report: Euthanasia and the Artificial Preservation of Life Project. ${ }^{92}$ In respect of legalizing voluntary active euthanasia the following fundamental rights are of importance:

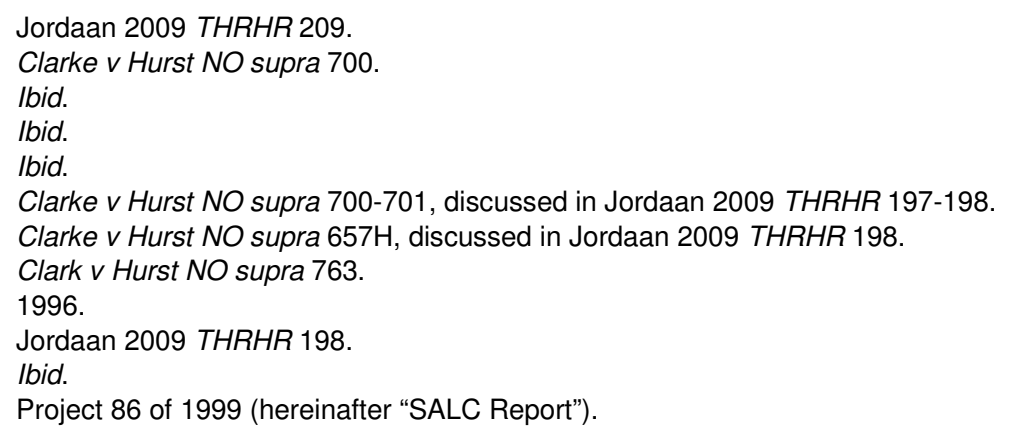


- Right to life (section 11).

- Right to dignity (section 10).

- The right to freedom and security of the person (section 12).

- The right to privacy (section 14). ${ }^{93}$

The Commission noted that the debate on the legalization of active euthanasia ought to be conducted with "total objectivity, in terms of constitutional principles. ${ }^{\prime 94}$ Although the SALC recommended the enactment of legislation to give effect to passive euthanasia, it did not go as far as making definite recommendations in relation to voluntary active euthanasia. ${ }^{95}$ However, it did provide three possible options for debate:

- Option 1: Confirmation of the present legal position

The arguments in favour of legalizing euthanasia are not sufficient reason to weaken society's prohibition of intentional killing since it is considered to be the cornerstone of the law and of all social relationships. Whilst acknowledging that there may be individual cases in which euthanasia may seem to be appropriate, these cannot establish the foundation of a general pro-euthanasia policy. It would furthermore be impossible to establish sufficient safeguards to prevent abuse. ${ }^{96}$

- Option 2: Decision-making by the medical practioner

The practice of active euthanasia is regulated through legislation in terms of which a medical practitioner may give effect to the request of a terminally-ill but mentally-competent patient to make an end to the patient's unbearable suffering by administering or providing a lethal agent to the patient. The medical practitioner has to adhere to strict safeguards in order to prevent abuse.

This option would make provision for both assisted suicide and voluntary active euthanasia. ${ }^{97}$

- Option 3: Decision-making by the medical practioner:

The practice of active euthanasia is regulated through legislation in terms of which a multi-disciplinary panel or committee is instituted to consider requests for euthanasia according to set criteria.

93 The Consitution of Republic of South Africa, 108 of 1996.

94 SALC Report 141, discussed in Jordaan 2009 THRHR 198.

95 Jordaan 2009 THRHR 199.

96 S 5(1) of SALC Report.

97 Mukheibir "The Implications of the End of Life Decisions Bill for Palliative Caregivers" 1999 Obiter 158171. 
The question that now needs to be addressed is whether the advent of the Constitution provides a fourth option in "securing one's right to die with dignity and assistance by informing the defence of consent". ${ }^{98}$ Regarding the issue of morality, it can be argued that causing a person's death is morally wrong when it is unauthorized, unjustified, and deprives a person of benefits that would otherwise have been afforded. No moral wrong, however, exists when these elements are absent. ${ }^{99}$ The obiter remarks in $S v$ Makwanyane, ${ }^{100}$ whilst not providing an answer to these questions, do suggest that the courts are at least considering this option:

"Does the 'right to life', within the meaning of section 9, preclude the practitioner of scientific medicine from withdrawing the modern mechanisms which mechanically and artificially enable physical breathing in a terminal patient to continue, long beyond the point when the 'brain is dead' and beyond the point when a human being ceases to be 'human' although some unfocused claim to qualify as a 'being' is still retained? If not, can such a practitioner go beyond the point of passive withdrawal into the area of active intervention? When? Under what circumstances?"

To what extent has the constitutional right to assisted suicide been recognized in rights-based jurisdictions? ${ }^{102}$ In South Africa, there is a general consensus that a blanket ban on euthanasia is lawful. The fact that the right to life is entrenched in the Constitution is proof of the value attributed to the sanctity of life. ${ }^{103}$ Section 36 clearly holds that the right to life cannot be waived or limited to accommodate euthanasia: where euthanasia is practised, there is no limitation of the right. Rather, the right is extinguished. ${ }^{104}$ Therefore, any proposed legislation will be in complete violation of the Constitution and $a b$ initio null and void. ${ }^{105}$ However, on closer examination of other rights contained in the Constitution, there may be compelling arguments for legalizing euthanasia. Consider section 12 of the Constitution. It provides the right to freedom and security of the person. In particular section 12(2)(b) which provides the right to bodily integrity, appears to provide a compelling argument that the right to freedom and security of person also includes personal decisions regarding the time and manner of a person's own death. ${ }^{106}$

A "determinative value" in issues of euthanasia is the "all encompassing" right to dignity. ${ }^{107}$ The lack of control over your destiny essentially involves a loss of dignity. It has been noted that "one of the paramount concerns of patients who wish to end their own, personal suffering is to preserve their dignity." ${ }^{108}$ The right to dignity and the qualified right to personal autonomy

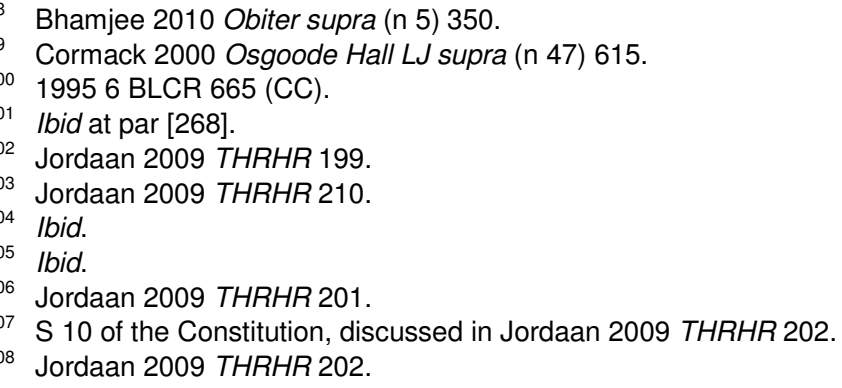


also inform section 14: the right to privacy which holds that an individual can make certain fundamental private choices without state interference. Surely this extends to how to end one's life? ${ }^{109}$ This choice could also involve consulting a physician to end one's life..$^{110}$

Prior to the advent of the Constitution ${ }^{111}$ this issue was addressed in Clarke $v$ Hurst NO. ${ }^{112}$ In this case the court expanded the grounds on which passive euthanasia may be exercised to include patients in a permanent vegetative state. ${ }^{113}$ The court noted that the wife (curatrix) of a patient who was in a persistent vegetative state for five years and who was being fed by means of nasal-gastric tube would not be acting unlawfully by authorizing the withholding of his life-support system. Although the court would not explicitly recognize the patient's right to self-determination (despite the existence of living will), ${ }^{114}$ this finding demonstrated a "small step on a long journey towards the legal recognition of a person's self-determination in regard to choosing the moment of his death". ${ }^{115}$ In determining the issue of unlawfulness, the prevailing values of society would have to be considered. The decision of that issue depends on the quality of life which remains for the patient. What the court (albeit unknowingly) referred to here was the right to dignity. The judge went on to note that the decision whether to undertake or to discontinue life-sustaining procedures will subsequently involve a balancing exercise. ${ }^{116}$

\section{8}

\section{DOES A BLANKET PROHIBITION ON EUTHANASIA INFRINGE THE RIGHT TO EQUALITY?}

The question that would need to be addressed in South African law is whether a blanket prohibition of voluntary active euthanasia amounts to an infringement of the right to equality and freedom from discrimination? ${ }^{117}$ In other words, does the differentiation between a competent patient who requests the withdrawal of treatment and a patient who requests active physician assistance with dying constitute unfair discrimination? ${ }^{118}$ Consider the way this issue is treated in the United States. In that jurisdiction the fundamental right to equal treatment before and subsequently through the

113 The definition of "persistent vegetative state" was defined as "a neurological condition where the subject retains the capacity to maintain the vegetative part of neurological function but has no cognitive function. In such a state the body is functioning entirely in terms of its internal controls. It maintains digestive activity, the reflex activity of muscles and nerves for low level and primitive conditioned responses to stimuli, blood circulation, respiration and certain other biological functions but there is no behavioural evidence of either self-awareness or awareness of the surroundings in a learned manner" (640D-F).

114 Clark v Hurst NO supra 638G-H.

115 Jordaan 2009 THRHR 197.

116 Clark $v$ Hurst NO supra 653E.

117 Jordaan 2009 THRHR 204.

118 Ibid.
} 
law is not absolute. ${ }^{119}$ In Peyler $v$ Doe ${ }^{120}$ the court noted that the "equal protection clause directs that all persons similarly circumstanced should be treated alike ... [however], the initial discretion to determine [this] resides in the legislatures." Furthermore, "when applying the equal-protection clause to most forms of state action ...the classification issue [must] bear some fair relationship to a legitimate public purpose.,"121 In Quill $v$ Vacco ${ }^{122}$ the Court of Appeals (for the Second Circuit) held that, despite the assisted-suicide ban's general applicability, "New York law does not treat equally all competent persons who are in the final stages of fatal illness and wish to hasten their deaths," because "those in the final stages of terminal illness who are on lifesupport systems are allowed to hasten their deaths by directing the removal of such systems; but those who are similarly situated, except for the previous attachment of life-sustaining equipment, are not allowed to hasten death by self-administering prescribed drugs". ${ }^{123}$ A finding of unequal treatment does not end the constitutional analysis. The question is whether this supposed unequal treatment was rationally related to any legitimate state interests. ${ }^{124}$ This question was posed in Cruzan $v$ Director, Missouri Health:

"WW]hat interest can the state possibly have in requiring the prolongation of life that is all but ended? Surely, the state's interest's lessens as the potential for life diminishes. And what business is it of the state to require the continuation of agony when the result is imminent and inevitable? What concern promotes the state to interfere with a mentally competent patient's right to define [his] own concept of existence, of meaning, of the universe and of the mystery of human life when the patient seeks to have drugs prescribed to end life during the final stages of a terminal illness?"

It would seem as if the state has several interests in prohibiting suicide. In Compassion in Dying $v$ State of Washington ${ }^{126}$ the court noted that these included:

- Protection of life.

- Prevention of suicide.

- Avoiding the involvement of third parties and the sue of arbitrary, unfair or undue influence.

- Protecting family members and loved ones.

- Protecting the integrity of the medical profession and

119 Labuschagne "Die Strafregtelike Verbod op Hulpverlening by Selfdoding: 'n Regsantropologiese Evaluasie" 1998 Obiter 4552.

120457 US 202, 216, 102 S Ct 2382, 2394, 72 L Ed 786, 798-799.

121 Peyler v Doe supra 758-759, discussed in Labuschagne 1998 Obiter 52.

122 Quill v Vacco supra 801.

123 Quill v Vacco supra 727 and 729.

124 Labuschagne 1998 Obiter 54.

125497 US 261, 110 S Ct 284, 111 L Ed 2d 224 (1990) 730, discussed in Labuschagne 1998 Obiter 54.

$12679 \mathrm{~F} 3 d 790$ (9 $9^{\text {th }}$ Cir 1996). 
- avoiding future movement towards euthanasia and other abuses [a slippery slope]. ${ }^{127}$

In Quill v Vacco ${ }^{128}$ the Court of Appeals concluded that "to the extent that [New York's statutes] prohibit a physician from prescribing medications to be self-administered by a mentally competent, terminally-ill person in the final stages of his terminal illness, they are not rationally related to any legitimate state interest". ${ }^{129}$ The problem is that such an argument would not have persuasive value in South African law. This is because the Constitutional Court subscribes to a substantive concept of equality as opposed to the United States which adopts a moral-formal approach. ${ }^{130}$ How would this translate in practice? Substantive equality requires the law to ensure equality of outcome. Therefore, the question is not whether particular individuals are treated differently but more whether the law affects those individuals in an equal manner. ${ }^{131}$ By allowing one person to end his/her life by refusing medical treatment but preventing another from achieving the same result by different means, results in the treatment being differential. ${ }^{132}$

Once differentiation has been established the next question is whether it amounts to unfair differentiation. ${ }^{133}$ If, for example, it is on a ground as specified in section 9(4) such as disability, discrimination will have been established. But if it is not, the enquiry will then turn on the "question of whether the ground is based on attributes and characteristics that have the potential to impair the fundamental human dignity of people as human beings". ${ }^{134} \mathrm{~A}$ blanket prohibition of physician-assisted suicide involves the human dignity of persons as human beings. Once discrimination has been established, the crux of the matter will be whether such discrimination is also unfair, which focuses primarily on the impact of the discrimination on the person and others in his situation. ${ }^{135}$

It is submitted that successful constitutional challenge of the blanket prohibition of active physician-assisted suicide is not ruled out in terms of such criteria in South African law. A case can be made that a terminally ill person who wants to end his/her life, but is physically unable to would be unfairly discriminated against if the law were to deny him/her the opportunity of dying in a way which is available to the able-bodied person: to commit suicide (which is also not illegal in South African law!) ${ }^{136}$ Consider these arguments in the context of the Pretty case. ${ }^{137}$

127 Compassion in Dying $v$ State of Washington supra 816-817, discussed in Labuschagne 1998 Obiter 54.

128 Quill v Vacco supra 801.

129 Quill v Vacco supra 731.

130 Jordaan 2009 THRHR 204.

131 Ibid.

132 Ibid.

133 Jordaan 2009 THRHR 205.

134 Ibid.

135 Jordaan 2009 THRHR 205. See for instance Harksen v Lane NO 1998 (1) SA 300 (CC) par [53].

136 Jordaan 2009 THRHR 205.

137 Pretty $v$ United Kingdom supra 1. 
In Pretty $v$ United Kingdom, ${ }^{138}$ the plaintiff suffered from a condition known as Lou Gehrig's disease (Amyotrophic Lateral Sclerosis). This disease attacks the motor neurons, the nerve cells located in the brain and along the spinal cord, degenerating the electrical impulses that send signals to an individual's muscles. As a result, the patient suffers from progressive muscle paralysis in the face, tongue, throat, respiratory system, shoulders, hands and legs. Once the disease has taken full effect, the patient cannot swallow, speak, cough or breathe unassisted but does remain mentally alert. The final stages of the disease are exceedingly distressing and undignified as the patient's inability to control his or her breathing leads to a complete failure of the respiratory system. ${ }^{139}$ The plaintiff argued that the refusal of the DPP to grant her husband immunity from prosecution (in the event that he assisted her suicide) amounted to an infringement of her right to respect for her private life ${ }^{140}$ which includes her right to self-determination. ${ }^{141}$

The European Court of Human Rights, in addressing her petition, noted that the right to life is significant. ${ }^{142}$ The court held that although prior case law did not directly address the issue of whether the right to selfdetermination fell within the scope of article 8, it would appear as if there is authority for the proposition that the "ability to conduct one's life in a manner of one's choosing may also include the opportunity to pursue activities perceived to be of a physically or morally harmful or dangerous nature for the individual concerned". ${ }^{143}$ By extension, article 8 would include "the right to choose when and how to die". ${ }^{144}$ In determining whether the United Kingdom had in fact interfered with her right to privacy, Lord Hope argued that "the closing moments of [Ms Pretty's] life [were] part of the act of living, and [that] she [had] a right to ask that [these moments] must be respected". ${ }^{145}$ The court agreed with Lord Hope and noted that "notions of the quality of life" have great value under article $8{ }^{146}$ Furthermore, the DPP's refusal to grant her husband immunity "diminished, or interfered with, Ms Pretty's ability to control her quality of life". ${ }^{147}$

The court referred to the case of Rodriquez $v$ Attorney General of Canada, ${ }^{148}$ where the Supreme Court of Canada, in applying the Canadian Charter to similar facts, concluded that prohibiting Ms Rodriquez from receiving assistance in suicide deprived her of her personal autonomy in the sense of the right to make decisions about one's own body and that a

138 Ibid.

139 Pretty v United Kingdom supra par [58], discussed in Nugent 2003 Journal of Transnational Law and Public Policy 187.

140 In terms of Article 8(1)-(2) of the Convention for the Protection of Human Rights and Fundamental Freedoms (1950).

141 Pretty $v$ United Kingdom supra 36, discussed in Jordaan 2009 THRHR 203.

142 Jordaan 2009 THRHR 203.

143 Pretty v United Kingdom supra 35, discussed in Nugent 2003 Journal of Transnational Law and Public Policy 193.

144 Ibid.

145 Pretty $v$ United Kingdom supra 22 (dissenting).

146 Pretty $v$ United Kingdom supra 37.

147 Ibid.

148 [1994] LRC 136. 
prohibition on assisted suicide "required justification under principles of fundamental justice". ${ }^{149}$ The court also concluded that the law of the United Kingdom, and not her illness, prevented her from exercising her privacy rights under the Convention. ${ }^{150}$

Despite these findings, the court in the second stage of its analysis held that the interference with Ms Pretty's right may be justified ${ }^{151}$ as "necessary in a democratic society" for the protection of others: "the notion of necessity implies that the interference corresponds to a pressing social need and, in particular, that it is proportionate to the legitimate aim pursued". ${ }^{152}$ The court held that states were entitled to regulate through the operation of criminallaw activities which can be detrimental to the safety and lives of others. ${ }^{153}$ Legislation is therefore designed to safeguard life by protecting those not in a condition to make informed decisions. ${ }^{154}$ The court further added that "it is the vulnerability of this particular category of persons which provides the rationale for the law in question and it is for the state to assess the risk and likely incidence of abuse if the general prohibition on assisted suicide were relaxed or if exceptions were to be created". ${ }^{155}$

Ms Pretty submitted that she was discriminated against as a result of not being treated in the same way as those whose situations were significantly different. Although the blanket ban on assisted suicide applied equally to all people in that jurisdiction, the effect of its application to her was discriminatory when she was so disabled that she could not end her life without assistance. ${ }^{156}$ Although the European Court of Human Rights noted that for the purposes of article 14 (equality clause), a difference in treatment between people in similar positions is discriminatory if it has no objective or reasonable justification: "[d]iscrimination may also arise where states without an objective and reasonable justification fail to treat differently persons whose situations are significantly different."157

Another right which is of relevance is section 11: the right to life. ${ }^{158}$ In Pretty ${ }^{159}$ the plaintiff contended that article 2(1)(right to life) ${ }^{160}$ protected the right to life, not life itself and established a right to choose whether to go on living. The corollary to this is whether it protected her right to avoid inevitable suffering and indignity. ${ }^{161}$ What this suggests is that the unqualified nature of

149 Pretty v United Kingdom supra 37, discussed in Nugent 2003 Journal of Transnational Law and Public Policy 194.

150 Pretty v United Kingdom supra 78.

151 Jordaan 2009 THRHR 203.

152 Pretty $v$ United Kingdom supra 38.

$153 \mathrm{Ibid}$, as discussed in Jordaan 2009 THRHR 203.

154 Ibid.

155 Pretty v United Kingdom supra 38, discussed in Jordaan 2009 THRHR 204.

156 Pretty $v$ United Kingdom supra 85, discussed in Jordaan 2009 THRHR 205.

157 Pretty v United Kingdom supra 88, as discussed in Jordaan 2009 THRHR 205.

158 Jordaan 2009 THRHR 206.

159 Pretty $v$ United Kingdom supra 1.

160 The relevant provision holds: "Everyone's right to life shall be protected by law. No one shall be deprived of his life intentionally save in the execution of a sentence of a court following his conviction of a crime for which this penalty is provided by law."

161 Pretty v United Kingdom supra 35, discussed in Jordaan 2009 THRHR 206. 
the right to life provides for an interpretation of the concept of life as something more than mere physical existence. ${ }^{162}$ This was acknowledged in $S \vee$ Makwanyane, ${ }^{163}$ where the court held that "[T]he right to life, thus understood, incorporates the right to dignity, so the rights to human dignity and life are entwined. The right to life is more than existence - it is the right to be treated as a human being with dignity; without dignity, human life is substantially diminished." 164 It is submitted that such an approach may provide a foundation for legal recognition and regulation of the practice of voluntary active euthanasia.

\section{HOW WOULD ADOPTING A RIGHTS-BASED APPROACH INFORM THE DOCTRINE OF CONSENT?}

To understand the role of consent in relation to murder, it is necessary to identify the prohibitory norm underlying murder and then apply it to the perpetrator's voluntary act. ${ }^{166}$ This means that it is necessary to evaluate the moral quality of the act independently of the justifying circumstance of consent. ${ }^{167}$ Therefore, to be able to understand in what circumstances consent may justify bodily injury, it will first be necessary to determine what constitutes criminal harm that a valid defence will need to override. ${ }^{168}$ Two kinds of harm exist: (1) setbacks to interests (not accompanied by a violation of rights) ${ }^{169}$ and (2) "morally indefensible"-rights violation. The latter is conceptualized as a justifiable setback to one's interests. ${ }^{170}$ For instance, voluntary consent would eliminate harm to the consenting person. In general a person does not have the right to be harmed by others but by giving consent to dental treatment, the person waives his/her claim of physical "inviolability" against the dentist, thereby transferring the privileged nonperforming acts which would otherwise constitute assault. ${ }^{171}$ In establishing whether consent can always change the moral and legal character of an act, it could be noted that while "certain free-floating evils" 172 have been criminalized in the past, to avoid moral harm to the community, these could have various criticisms. Most notably is police enforcement which could lead to a society filled with fear, persecution and alienation. Furthermore, the majority of society could end up being regarded as criminals. ${ }^{173}$ Consider the

\footnotetext{
162 Jordaan 2009 THRHR 207.

163 S v Makwanyane supra 665.

164 S v Makwanyane supra par [326]-[327].

165 Jordaan 2009 THRHR 207.

166 Bergelson "The Right to be Hurt: Testing the Boundaries of Consent" 2007 George Washington LR 166210.

167 Ibid.

168 Ibid.

169 Bergeleson 2007 George Washington LR 214. Eg, a competitor's success which financially harms a neighboring business, even though the competitor has done nothing wrong.

170 Bergeleson 2007 George Washington LR 214.

171 Ibid.

$172 \mathrm{Eg}$, adultery, gladiatorial contests, cannibalism and organ harvesting.

173 Bergelson 2007 George Washington LR 215. For instance Bergelson uses the example of adultery.
} 
case of Armin Meiwes, a German computer technician who posted a message in an Internet chat room devoted to cannibalism that he was seeking a man for slaughter. ${ }^{174}$ It does not matter that Miewes treated the victim with respect. Cannibalism denies a person's equal moral worth and assaults the victim's dignity. Further, the concept of dignity should be viewed objectively: that is, people are entitled to basic respect. Therefore, dignity should be shared by the community at large, not only by certain segments. ${ }^{175}$

Does consent have the power to change the moral and legal character of person's actions? ${ }^{176}$ If an infringement of the right to dignity ${ }^{777}$ can be used to criminalize consensual behaviour, we override an individual's liberty (partly paternalistic, but in a large part for society as a whole).$^{178}$ Consider the reality-television series "The Fear Factor". The show violates the participants' dignity. However serious the threat to participants or society, it is not sufficient to justify its ban. ${ }^{179}$ It could be suggested that criminal harm should not be limited to a rights violation then. For example, gladiatorial contests are unacceptable because they violate the dignity of participants which is essential to our humanity. ${ }^{18}$

When encroaching on a person's liberty, the threat to society should be serious enough to warrant criminal sanction. What becomes apparent is that a broader theory of harm is needed than one based entirely on rights. ${ }^{181}$ The function of criminal law is to protect human dignity and other aspects of humanity, not just autonomy. The reason that violations of autonomy are punished "is because we view autonomy as an essential aspect of humanity." 182

From a conceptual point of view a rights violation could be viewed as a wrongful setback to an interest. ${ }^{183}$ Traditional criminal theory protects the most "essential welfare interests" from wrongful interference by others, whereas wrongfulness is understood as a violation of autonomy. ${ }^{184}$ The concept of wrongfulness is in need of a revision so that it will reflect a broader meaning of harm. What is morally objectionable is not only disregarding one's will but also rejecting human dignity. ${ }^{185}$ By including a violation of dignity in the concept of "wrong", harm could continue to be defined as a wrongful setback to an interest, where "wrongful" can mean

174 Finn Cannal case Grips Germany; Suspect Says Internet Correspondent Volunteered to Die, Washington Post 4 December 2003 A26, discussed in Bergelson 2007 George Washington LR 167.

175 Bergelson 2007 George Washington LR 217.

176 Bergelson 2007 George Washington LR218.

177 In terms of $\mathrm{s} 10$ of Act 108 of 1996.

178 Bergelson 2007 George Washington LR 218.

179 Ibid.

180 Bergelson 2007 George Washington LR 215.

181 Bergelson 2007 George Washington LR 219.

182 Ibid.

183 Ibid.

184 Ibid.

185 Ibid. 
either that which violates a right (that is, autonomy) or that which violates the victim's dignity. ${ }^{186}$

\section{HOW WOULD THESE PRINCIPLES APPLY IN PRACTICE?}

To have a right means to have a claim to a certain moral status. ${ }^{187}$ Consent is a way to change this status unilaterally. This occurs by transferring to another person "a claim, privilege, power or immunity". ${ }^{188}$ It gives them rights they did not have before, but does not impose obligations on them. It simply provides a choice. Even if this waiver is combined with a request, the person still has a choice in following it. ${ }^{189}$ In cases of euthanasia, a consensual setback to the victim's interest that protects his/her dignity should be justifiable. Mercy-killing of a suffering terminally-ill patient although destroying his interest in continued living, when based on the patient's plea, the killing respects and preserves the dignity of the dying person and therefore should not be subject to criminal liability. ${ }^{190}$ The more serious (disabling and irreversible) the impediment to the victim's interests, the more compelling the reason must be for the harmful action. The courts, by adopting this balancing test will improve the current rule significantly which completely disregards both her reasons for harmful actions and the relative amount of harm as soon as the injury reaches the threshold of being serious. $^{19}$

In Glucksberg ${ }^{192}$ the issue of balancing became an obstacle. The Supreme Court weighed the putative harms and interests that are associated with cases of assisted suicide. It was held that the value of one's life to others is too substantial to allow a person complete autonomy. ${ }^{193}$ The other justices found the harm of involuntary suicide sufficiently grave to outweigh the harm endured by the terminally ill. ${ }^{194}$ The "rights claim" was adjudicated by prioritizing the conflicting values at stake rather than putatively balancing the interests of the individual and the state. ${ }^{195}$ It becomes evident that the subordination of autonomy to moral theory

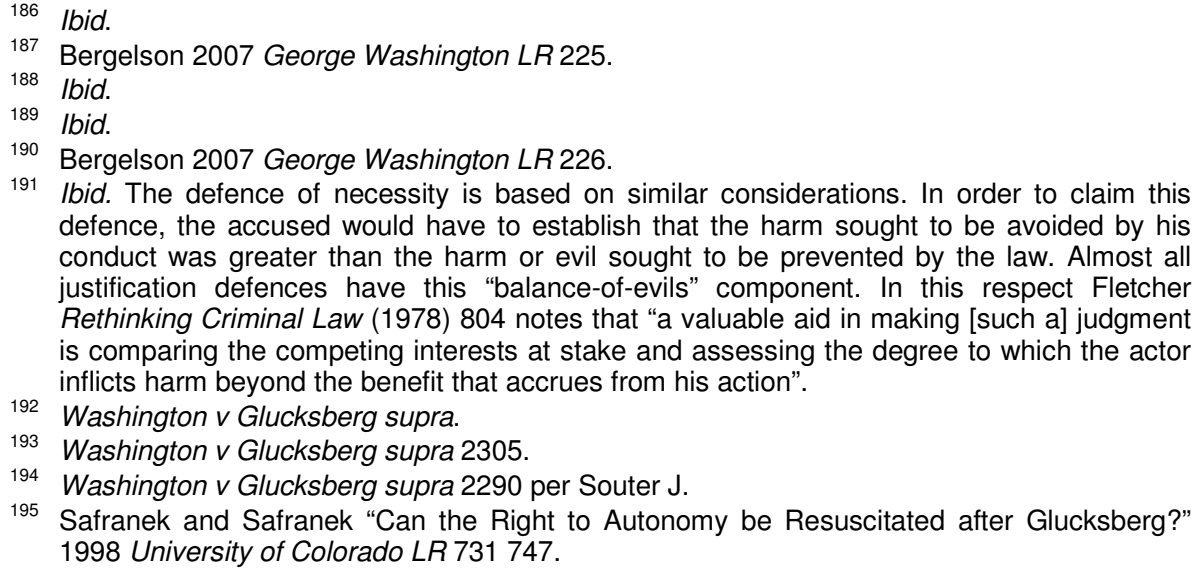
conduct was greater than the harm or evil sought to be prevented by the law. Almost all justification defences have this "balance-of-evils" component. In this respect Fletcher Rethinking Criminal Law (1978) 804 notes that "a valuable aid in making [such a] judgment is comparing the competing interests at stake and assessing the degree to which the actor inflicts harm beyond the benefit that accrues from his action".

192 Washington v Glucksberg supra.

193 Washington v Glucksberg supra 2305.

194 Washington v Glucksberg supra 2290 per Souter J.

195 Safranek and Safranek "Can the Right to Autonomy be Resuscitated after Glucksberg?" 1998 University of Colorado LR 731747. 
undermines "several influential strains of contemporary legal theory". The court claims that it is neutral toward competing views of good. Furthermore, certain legal scholars (political liberals) require state neutrality; otherwise the state would violate the equal respect and other important obligations that are owed to each member of society. ${ }^{196}$ But given that the interests in Glucksberg ${ }^{197}$ reflect "a view of the good, the court's decision clearly violates the political liberals' requirement of state neutrality". ${ }^{198}$

Another strain of contemporary liberalism (comprehensive liberalism) acknowledges that the state "ultimately imposes moral theory and supports state action that promotes individual autonomy". ${ }^{199}$ The problem is that due process adjudication is the criterion that differentiates those autonomous acts meriting constitutional protection. Therefore, even when choosing to promote autonomy, certain autonomous acts will have to be prioritized. ${ }^{200}$ In Glucksberg $^{201}$ this approach calls for a court to assess the relative "weights" or dignities of the contending rights. In this case a person's "negative autonomy to avoid involuntary euthanasia and maintain the value of human life was accorded axiological priority over the positive autonomy to terminate a painful existence". ${ }^{202}$ It would seem as if the ethical basis of autonomy could threaten the exercise of judicial review. ${ }^{203}$ This critique would be relevant to South African law as well. Nevertheless, these concerns can be dispensed with. It is submitted that "although a person [would] remain the locus of moral agency, responsibility and independence, the term deliberative autonomy [does] allow room for social dimension". ${ }^{204}$ In other words, the decision to end one's life would be taken by consulting with others and taking their views into account. ${ }^{205}$ The SALC Report ${ }^{206}$ makes it a criterion that a physician be satisfied that ending the life is the only way for the patient to be relieved of his suffering. ${ }^{207}$ It follows, therefore, that options for palliative care be considered before a request for euthanasia is granted. ${ }^{208}$ It is clear that as long as there are procedural safeguards in place, the risk of arbitrary conduct will be minimized. ${ }^{209}$

To continue, an objectively justifiable outcome of the harmful consensual act is a precondition of the justification defence, but it is not adequate. To be completely exculpated, the accused must demonstrate something more. ${ }^{210}$

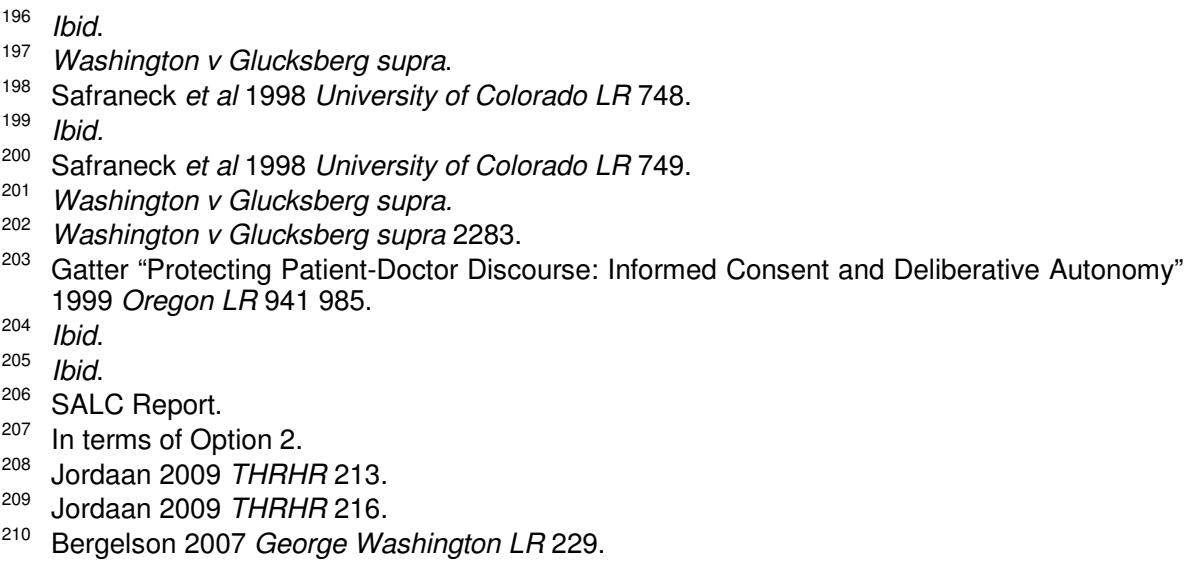


Proper mens rea ${ }^{211}$ is essential for the availability of a justification. The basis for this requirement can be explained as follows: while we do not give people licence to break the law, we tolerate it to the extent that it is necessary to achieve the lesser-evil outcome. ${ }^{212}$ This raises an important question: what level of awareness does the accused need to have of the justifying circumstance to deserve moral and legal justification? It is submitted that the answer is purpose: "[a]ny justifiable conduct requires good faith and, in the context of a limited licence to overstep a prohibitory norm, the requirement of good faith should be satisfied only when the subjective purpose of the perpetrator is directed towards the goals for which the licence is granted". ${ }^{213}$ Therefore, to qualify for the defence of justification, the accused must:

- have knowledge of the justifying circumstance; and

- a purpose specifically directed at it. ${ }^{214}$

In relation to the question of what the purpose should be, it is submitted that merely "fulfilling one's desires" is both over- and underinclusive. This view is overinclusive because fulfilling another person's desires is not always necessary for a lawful, yet harmful act. For instance in the case of a boxing champion who may use another party as a sparring partner (punching bag) without focusing on their desires. ${ }^{215}$ It is underinclusive in the sense that in terms of the Meiwes example, Miewes did satisfy Brandes's desires. He even cooked part of Brandes's body satisfying the latter's fancy of letting his killer "dine from his live body" and shared the snack with his victim. ${ }^{216}$ Therefore what appears to be a better theory is that:

"consent is related to other justification defences on a slightly more abstract level: like other justifications, it requires both the subjective awareness of necessary and permissive conditions and a good reason, namely the purpose to bring about a better balance of harms/evils and benefits than that which would exist without the perpetrator's action. Just as with the requirement of an objectively positive outcome, this subjective purpose may include interests of other people and not merely the victim. At the same time, similarly to the objective requirement for justification, the perpetrator may not aim at significantly setting back the victim's interest while, at the same time, disregarding his dignity."

From a theoretical point of view, it places the defence of consent squarely within the family of justification defences: these seek to overcome the

211 Eg, consider the Model Penal Code ss $3.02 \mathrm{cmt} 2$. which states that to qualify for a defence of necessity, the actor must actually believe that his conduct is necessary to avoid an evil. 212 lbid.

213 lbid.

214 Bergelson 2007 George Washington LR 231. Eg, under the Model Penal Code ss 3.04(b)(i) (1985), a person may not defend his life with deadly force if he provoked the attack "with the purpose of causing death or serious bodily harm" to the current attacker. To contrast this, an initial aggressor who did not have such a purpose still retains the right to use deadly force. Clearly an earlier wrongful purpose would destroy the privilege of self-defence by (230).

216 B Bergelson 2007 George Washington LR 231.

217 Bergelson 2007 George Washington LR 231-232. 
deontological constraint against the intentional causing of harm. ${ }^{218}$ The question about a good reason addresses both prongs of the evil to be prevented by criminalizing consensual acts that set back important human interests and disregard of the victim's dignity. The good reason to harm must negate either kind of harm, on the objective and subjective. ${ }^{219}$ Where the actors actions don't violate rights and produce a positive balance of harms/evils he is entitled to a complete justificatory defence. For example, a mountaineer who to save the life of an injured friend (and with his consent) cuts off his leg to save his life. ${ }^{220}$ Similarly a consensual setback to the victim's interests that protects the victim's dignity should be justifiable. ${ }^{221}$ As has been noted "the core underlying notion of human rights is that individuals will not be sacrificed to the social good, at least without overwhelming or compelling justification".222

For example, a mercy killing of a terminally ill patient destroys his continued interest in living but if based on the patient's plea, it preserves the core constitutional rights of the victim. For instance the right to dignity. ${ }^{223}$ The right to life without a basic quality of life that is the existence of conditions which enable a person to enjoy human existence would be deemed senseless. ${ }^{224}$ For example, in the case of Pretty $^{25}$ the court did not properly address the interaction of the right to life and the concomitant claim to a basic quality of life. ${ }^{226}$ Further, in relation to the right to respect for private autonomous decisions, in Pretty's case it was clear that "without in any way negating the principle of sanctity of life protected under the Convention, the court considered that under Article 8 that notions of quality of life taking on significance. In an era of growing medical sophistication combined with longer life expectancies, many people are concerned that they should not be forced to linger on in old age or in states of advanced physical or mental decrepitude which conflicts with strongly held ideas of self and personal identity". ${ }^{227}$ Ms Pretty was prevented by the law from utilizing assisted suicide to avoid an undignified and distressing end to her life. ${ }^{228}$ This contention finds support in section 10 of the Constitution ${ }^{229}$ but also in case law. The unqualified nature of the right to life in the Constitution provides for a wider interpretation of the concept of life: as something more than mere

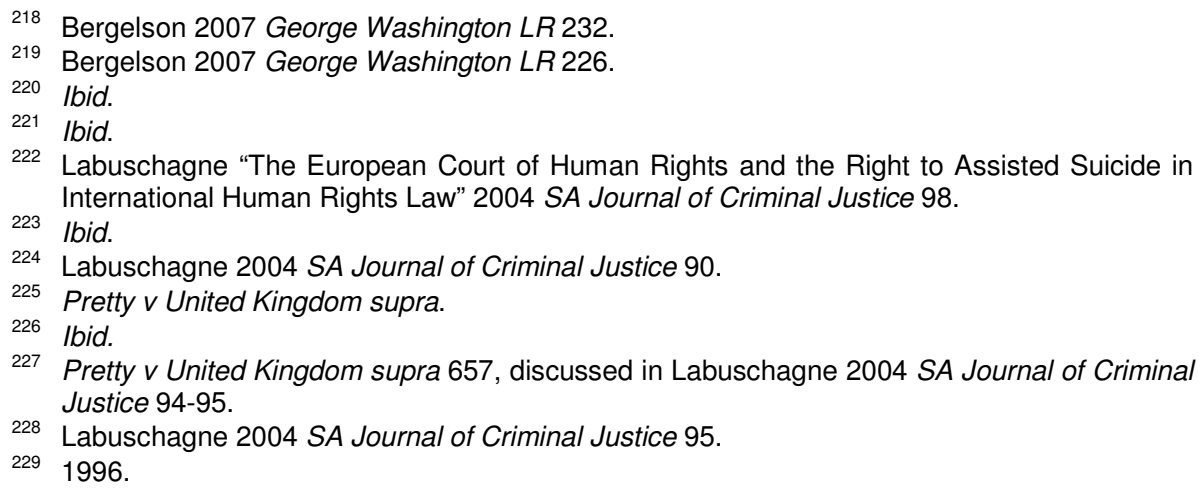


physical existence. In other words, this would signify at least a certain quality of life. ${ }^{230}$ As was held in $S v$ Makwanyane: ${ }^{231}$

"[The right to life was included in the Constitution not simply to enshrine the right to existence. It is not life as mere organic matter that the Constitution cherishes, but the right to human life: the right as a human being, to be part of a broader community, to share in the experience of humanity, this concept of human life is at the centre of our constitutional values. The Constitution seeks to establish a society where the individual value of each member of the community is recognized and treasured. The right to life is central to such a society, The right to life, thus understood, incorporates the right to dignity, So the rights to human dignity and life are entwined, The right to life is more than existence - it is the right to be treated as a human being with dignity. Without dignity, human life is substantially diminished. Without life, there can be no dignity.

Lastly, her right to equality ${ }^{233}$ was infringed since English law permitted able-bodied persons to resort to suicide to escape their misery but refused taking into consideration the fact that she was incapacitated and therefore failed to distinguish between those who were able and those who were unable to commit suicide, thereby seriously undermining the protection of life and greatly increasing the potential for abuse. ${ }^{234}$

Although it may be difficult to determine what qualifies as a good reason this balancing of evils component forms part of all justification defences. In cases of consent, the consent of the victim may serve as a defence only if the perpetrator's acts results in the objectively positive balance of harms/evils and benefits. For instance, gladiatorial matches are unacceptable not only due to the potential for death or injury (setback to vital interests) and indignity of turning human death into a show but further the benefits (entertainment for spectators and prize money for participants) are minimal compared to the quality and quantity of the harm involved. ${ }^{235}$ To contrast this example, there has been a call for the legalization of organ sales since donation does not provide enough. In such a case, the setback to the sellers' health may be balanced by benefits purchased with the proceeds of sale and the sellers dignity will not suffer more than with the donation of blood for example. Simultaneously the benefit of saved human lives would add to the dignity transaction and produce more good than evil. ${ }^{236} \mathrm{An}$ act is further overall justifiable even if it is not only limited to the victim's interests. For instance, in the case of a lifeboat in which the volunteers who agreed to sacrifice their lives had to be pushed overboard: they destroyed the victims' interests in continued living but neither violated their rights, nor disregarded their wishes and in addition saved numerous

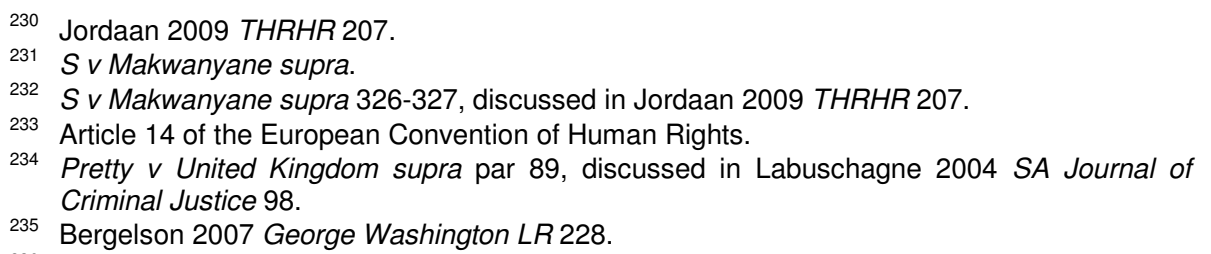


lives which would otherwise have been lost. ${ }^{237}$ It could be said that if an act provides a measurably positive outcome, the act is justified by the outcome itself and therefore consent is irrelevant. ${ }^{238}$ This is not correct since, if the victims in the lifeboat did not volunteer, no number of saved would justify their killing. ${ }^{239}$ The test also makes sense since it requires proof of the perpetrators good faith and benevolent purpose. On the other hand the accused would not have had to prove that he was motivated by a noble goal of a particular kind. In most cases people have more than one motive for their actions. Dr Kevorkian admitted that his motive for killing the victim suffering from Lou Gehrig's disease was "to relieve his pain and suffering and bring the issue of euthanasia the forefront". ${ }^{240}$ As Bergelson notes "we may not like some of the perpetrator's motives, however, as long as (1) the perpetrator intended to achieve, and in fact achieved, a positive balance of evils, and (ii) the consensual harmful act neither aimed at, nor resulted in, substantial harm to the victim's interests and dignity, the perpetrator should be justified". ${ }^{241}$

\section{CONCLUSION}

The advent of the Bill of Rights now gives us compelling reasons for legalizing euthanasia. Section 10 of the Constitution guarantees a number of rights, most importantly the right to dignity. Similarly, the right to dignity and the qualified right to autonomy inform section 14 which holds that individuals are entitled to make certain choices without state interference. At present, the current criminal law only recognizes consent of the victim as a defence to bodily harm in limited circumstances. This article is an attempt to provide a principled alternative: one that necessarily focuses on a rights-based approach. By revising the law, the victim's consent to harm would function as an affirmative defence. South African law would be able to take explicitly into account the victims shared responsibility by reducing the perpetrator's fault. This would result in a balance being reached between public and private interests, thereby giving weight to the victim's autonomous decisions while simultaneously protecting the victim's dignity from harm. By adopting a rule based on a uniform principle that is common to other justification defences would lead to consistent and morally sustainable verdicts. That is, to be entitled to a complete defence, the accused has to prove that in addition to the victim's consent, there had to be a good reason for his harmful action: he intended to achieve a better balance of harms/evils and benefits compared to that which would necessarily have resulted from inaction, with the proviso that the accused's act neither aims nor actually harms the victim's essential welfare interests and his dignity.

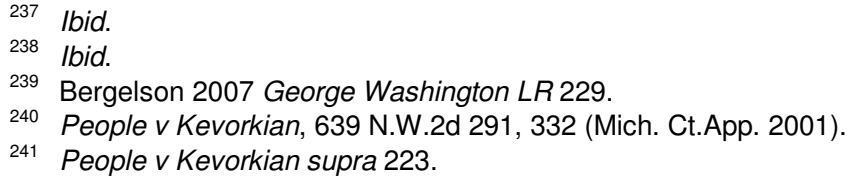

